\title{
Oxidative Stress Defence Response of Carica papaya Challenged by Nitric Oxide, Papaya meleira virus and Saccharomyces cerevisiae
}

\author{
David Shaun Buss ${ }^{1}$, Germana Bueno Dias ${ }^{1, \dagger}$, Mirella Pupo Santos ${ }^{1, \dagger}$, Jose Aires Ventura ${ }^{1,2}$ and \\ Patricia Machado Bueno Fernandes ${ }^{*}, 1$ \\ ${ }^{I}$ Núcleo de Biotecnologia, Universidade Federal do Espirito Santo, Av. Marechal Campos, Vitória, ES, Brazil \\ ${ }^{2}$ Instituto Capixaba de Pesquisa, Assistência Técnica e Extensão Rural, INCAPER, 29052-010 Vitoria, ES, Brazil
}

\begin{abstract}
Seedlings of papaya (Carica papaya), cultivar Golden, were exposed to a nitric oxide donor, sodium nitroprusside (SNP), Papaya meleira virus (PMeV) and yeast (Saccharomyces cerevisiae, as a model fungal elicitor). The aim was to investigate the response of $C$. papaya to infection and the role of nitric oxide in this process. SNP alone led to a short lived $(6 \mathrm{~h})$ burst of peroxidase activity and a relatively low level thereafter, although higher than the control, whilst the virus PMeV caused a sustained increase for at least 30 days. In contrast, both SNP and PMeV treatments increased superoxide dismutase activity for at least 30 days. In general, concomitant addition of PMeV and SNP produced the highest increases in peroxidase and superoxide dismutase activity over the 30 day time course. Levels of phenolics were elevated after addition of SNP and histochemistry confirmed increased peroxidase and superoxide dismutase activity, especially around the phloem cell walls, suggestive of lignification. Carbohydrate content was also elevated after SNP treatment, in particular saccharose. Treatment with yeast produced increased peroxidase activity and phenolic and carbohydrate content in the plant tissues. These results demonstrate some of the defences elicited in Carica papaya in response to infection, and the role of nitric oxide in this process. The apparent systemic acquired resistance displayed suggests that artificial initiation of this process might be a useful future technique against $\mathrm{PMeV}$ in the horticultural industry.
\end{abstract}

Keywords: Antioxidant, carbohydrate, Carica papaya, nitric oxide, Papaya meleira virus, peroxidase, superoxide dismutase.

\section{INTRODUCTION}

Papaya (Carica papaya) is a major fruit crop in many tropical parts of the world. It has been ranked first amongst 38 common fruits based on it's accordance to the United States Recommended Daily Allowance for many vitamins and consumption of papaya has been recommended for preventing vitamin A deficiency [1] which causes childhood blindness in many tropical and subtropical countries.

Unfortunately, papaya is susceptible to multiple pathogens. Susceptibility to Papaya ringspot virus has been largely contained by genetic modification [2], but there are other important challenges to papaya cultivation. A significant viral disease of papaya is "sticky disease" or "meleira", which can cause loss of up to $100 \%$ of the crop in a plantation. It is caused by a virus, Papaya meleira virus $(\mathrm{PMeV})$, a double stranded RNA virus of approximately 12 $\mathrm{kbp}$ [3]. So far PMeV has only been found in the lactifers of papaya [4], an environment normally hostile to microorganisms. PMeV induces potassium phosphate accumulation in the lactifer, changing the osmotic balance and

\footnotetext{
*Address correspondence to this author at the Universidade Federal do Espírito Santo, CCS, Núcleo de Biotecnologia, ES, Brazil; Tel: (55) 27 - 33357348; Fax: (55) 27 - 2122 7275;

E-mail: patricia.fernandes@pq.cnpq.br

${ }^{\dagger}$ Present address; Universidade Estadual do Norte Fluminense Darcy Ribeiro, Av. Alberto Lamego, RJ, Brazil
}

increasing the water content, whilst reducing the content of sugars and proteins [5]. This leads to the exudation of a watery latex solution from fruit and leaves which oxidises in air creating a black sticky mass on the plant surface, giving the disease it's name. As well as the unpleasant appearance, changes in the texture and flavour of the fruit render it unsaleable. Control of $\mathrm{PMeV}$ infection is by identification of infected plants by symptoms and molecular diagnosis and removal of these plants as there are no resistant varieties [6]. It is important therefore to understand and eventually enhance the natural response of papaya plants to viral attack.

A major defence mechanism in plants is the "hypersensitive response" (HR) whereby cells infected with pathogens, and often surrounding cells as well, are instructed to self-destruct by the host plant [7]. This is thought to deny nutrients to the invading pathogen. It is proposed that in plants the process is initiated by a reaction between nitric oxide (NO) and hydrogen peroxide $\left(\mathrm{H}_{2} \mathrm{O}_{2}\right)$, which is formed by superoxide $\left(\mathrm{O}_{2}^{-}\right)$dismutation by superoxide dismutase (SOD) during the HR [8].

Many studies have correlated a burst of NO production with plant defence responses against pathogens. This process has been demonstrated in fungal [9], bacterial [10] and viral [11] infections and NO accumulation usually reaches a peak 4 to $6 \mathrm{~h}$ after pathogen recognition. Administration of $\mathrm{NO}$ donors such as sodium nitroprusside (SNP) induces the expression of defence genes such as phenylalanine lyase 
(PAL) $[10,11]$ and also SOD [13]. As well as an involvement in the hypersensitive response, it has been demonstrated that NO has the capacity to induce post translational modifications in plant proteins such as nitrosylation, nitration and oxidation [12], and these alterations have the potential to alter the activity of regulatory proteins $[14,15]$.

Complimenting the sizeable production of $\mathrm{NO}$ and reactive oxygen species (ROS) such as $\mathrm{O}_{2}^{-}$, plants possess a number of antioxidant defences. Peroxidases, together with catalases, are the major $\mathrm{H}_{2} \mathrm{O}_{2}$ degrading enzymes in plant cells [16], although the reaction of peroxidases with $\mathrm{H}_{2} \mathrm{O}_{2}$ is a process which can lead to lipid peroxidation and thus membrane damage [17]. Several authors have found a relationship between peroxidase levels and resistance to fungal [18-20] or viral [21,22] pathogens.

As well as oxidative responses, we also determined to investigate other components of the plant defence system. Increases in carbohydrate titres are a general plant response to stress [23]. However, more specific links to different stresses can be made and carbohydrate levels have been shown to increase in response to infection by studies since the 1930s, (for example [24-26]). A link of carbohydrates with oxidative stress also seems clear as carbohydrates have been shown to provide protection against ROS [27], induce oxidative stress defences [28] and are essential in the production of many anti-oxidants [29]. Plant phenolics are also an important part of plant protection against fungi and bacteria [30], and titres are often elevated following infection $[31,32]$. Plant phenolics are also effective against viruses, and are induced by virus infection [33] which has led to a number of studies of the possibility of their use against human viruses (reviewed in [34]).

In summary, we proposed to study the response of Carica papaya to pathogen attack in general, and to the virus $\mathrm{PMeV}$ in particular, and determine any role of nitric oxide in these processes.

\section{MATERIALS AND METHODS}

\section{Vegetative Material}

The seedlings of cultivar Golden used in the experiments were obtained from the experimental farms of INCAPER (Instituto Capixaba de Pesquisa, Assistência Técnica e Extensão Rural), located in the state of Espirito Santo, Brazil. Seeds were planted in pots in a mixture of compost to sand of 3:1 (w:w). Seedlings were irrigated 3 times per week. At four months, seedlings were transferred to a glasshouse with mean temperature of $20{ }^{\circ} \mathrm{C}$ and a photoperiod of $12 \mathrm{~h}$. At this stage, seedlings were divided into experimental groups.

\section{Experimental Plan}

Seedlings were treated with the NO donor sodium nitroprusside alone or in combination with Saccharomyces cerevisiae or PMeV. Seedlings were initially treated with the NO donor sodium nitroprusside or Saccharomyces cerevisiae at 72,120 and $168 \mathrm{~h}$ to determine the time course and magnitude of responses to NO donation and pathogen challenge. The second tranche of studies focused specifically on interactions of $\mathrm{NO}$ and the virus $\mathrm{PMeV}$, over a more comprehensive time scale from 3 min to 30 days. It has been reported that mechanical perturbation from spraying can cause changes in gene expression in C. papaya [35] and to assess this, and differentiate it from other treatments, controls of untreated and water sprayed plants were included.

\section{Treatment with Nitric Oxide (NO)}

Cuttings were sprayed with $5 \mathrm{ml}$ of $10 \mathrm{mM}$ sodium nitroprusside solution (SNP), [36] or the same volume of distilled water as a control. Sodium nitroprusside solution was used as it is the most widely accepted experimental donor of $\mathrm{NO}$ [37].

\section{Treatment with Yeast Saccharomyces Cerevisiae}

A fresh suspension of $200 \mathrm{~g} \mathrm{l}^{-1}$ yeast (Fleishmann Ltda, Sao Paulo, Brazil) was prepared. The solution was autoclaved for $30 \mathrm{~min}$ at $121{ }^{\circ} \mathrm{C}(1 \mathrm{~atm})$ and the plants were sprayed with $10 \mathrm{ml}$ of solution.

\section{Treatment with Papaya Meleira Virus (PMeV)}

Latex was collected from infected plants and the presence of PMeV confirmed by gel electrophoresis [6]. This was used as the source of $\mathrm{PMeV}$ inoculate in the treatments. Seedlings of cultivar Golden, 4 months of age, were injected with $20 \mu 1$ of latex from an infected plant in the leaf petiole. Five replicates were used for each treatment.

\section{Total Protein Content}

The protein content of the seedlings was determined according to the method of Lowry [38] with absorbance measured at $660 \mathrm{~nm}$ (FEMTO 482, spectrophotometer, FEMTO, Sao Paulo, Brazil). For preparation of the crude extract $0.3 \mathrm{~g}$ of leaves were crushed in liquid nitrogen and resuspended in $4 \mathrm{ml}$ of $0.01 \mathrm{M}$ phosphate buffer ( $\mathrm{pH} 6.0$ ) at 4 ${ }^{\circ} \mathrm{C}$. The suspension was centrifuged at $12,000 \mathrm{rpm}$ for 25 min at $4{ }^{\circ} \mathrm{C}$ and the supernatant collected. To $1 \mathrm{ml}$ of crude extract was added $5 \mathrm{ml}$ of copper reagent ( $48 \mathrm{ml}$ of sodium carbonate solution $(3 \%$ in $0.1 \mathrm{M} \mathrm{NaOH}), 1 \mathrm{ml}$ sodium potassium tartarate solution (4\%) and $1 \mathrm{ml}$ Copper sulphate solution (2\%)). After $10 \mathrm{~min}, 500 \mu 1$ of phenol reagent (1 volume of Folin-Ciocalteu reagent and 2 volumes of distilled water) was added and incubated for $10 \mathrm{~min}$. Absorbance was measured at $660 \mathrm{~nm}$. To determine the concentration a standard curve was prepared using aliquots of bovine serum albumin $\left(25,50,100, \& 150 \mu 1\right.$ of $\left.1 \mathrm{mg} \mathrm{ml}^{-1}\right)$.

\section{Peroxidase Activity}

Peroxidase activity was determined using a previously published method [39] with some modifications. Leaves $(0.3$ g) were crushed in liquid nitrogen and resuspended in $4 \mathrm{ml}$ of extraction buffer (phosphate buffer, $0.01 \mathrm{M}, \mathrm{pH} 6.0$ ) at 4 ${ }^{\circ} \mathrm{C}$. The suspension was centrifuged at $12,000 \mathrm{rpm}$ for 25 min at $4{ }^{\circ} \mathrm{C}$ and the supernatant was collected. To $60 \mu 1$ of supernatant were added $0.9 \mathrm{ml}$ of reaction buffer $(0.15 \mu 1$ of $30 \% \mathrm{H}_{2} \mathrm{O}_{2}, 0.13 \mu 1$ of guaiacol in $50 \mathrm{ml}$ extraction buffer) and $40 \mu 1$ of extraction buffer. Absorbance was read at $470 \mathrm{~nm}$ and activity expressed as Abs $\mathrm{min}^{-1} \mathrm{mg}^{-1}$ protein. 


\section{Determination of the Activity of Superoxide Dismutase (SOD)}

Superoxide dismutase activity was determined using a previously published method [40]. Frozen leaves (0.3 g) were homogenised with polyvinylpyrrolidone (PVPP) in a solution of $50 \mathrm{mM}$ phosphate buffer, $\mathrm{pH} 7.5,1 \mathrm{mM}$ EDTA$\mathrm{Na}_{2}, 50 \mathrm{mM} \mathrm{NaCl}$ and $1 \mathrm{mM}$ ascorbic acid. The homogenate was centrifuged at $11,000 \mathrm{rpm}\left(30 \mathrm{~min}, 4{ }^{\circ} \mathrm{C}\right)$. To the supernatant was added $0.5 \mathrm{ml}$ of $0.54 \mathrm{mM}$ EDTA-Na, 0.8 $\mathrm{ml}$ of phosphate potassium buffer $(0.1 \mathrm{M}, \mathrm{pH} 7.0), 0.5 \mathrm{ml}$ of $0.13 \mathrm{mM}$ methionine, $0.5 \mathrm{ml}$ of $0.44 \mathrm{mM}$ p-nitroblue tetrazolium (NBT) and $0.2 \mathrm{ml}$ of $1 \mathrm{mM}$ riboflavin. The resultant solution was exposed to fluorescent light $(80 \mathrm{~W})$ for $20 \mathrm{~min}$.

Extracts prepared following the same procedure were kept in the dark. The absorbance of the solution was measured by spectrophotometer $(\lambda=560 \mathrm{~nm})$ for both types of extract (illuminated and not illuminated). SOD activity was determined by comparison of the difference between the two absorbances, reflecting inhibition of NBT reduction by the enzymatic activity of SOD. Enzymatic activity was

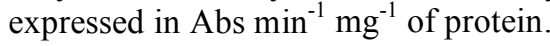

\section{Microscopy}

Leaf stems were examined histochemically for the presence of superoxide $\left(\mathrm{O}_{2}{ }^{-}\right)$and Hydrogen peroxide $\left(\mathrm{H}_{2} \mathrm{O}_{2}\right)$ following treatment (time points 3, 15, 30, 45, 60, 180 and $360 \mathrm{~min}$ ). Results were recorded digitally using a Leica optical microscope with Moticam 20002.0 pixel camera and Motic Plus Soft Imaging software.

\section{i) Detection of Superoxide $\left(\mathrm{O}_{2}^{-}\right)$}

Detection followed the histochemical method of [41] with some modification. Traverse sections of the leaf stem were cut by hand free and deposited in Petri plates containing a solution of $0.5 \mathrm{mM}$ nitroblue tetrazolium (NBT), pH 7.4, for $12 \mathrm{~h}$. Control samples were maintained in deionised water. All sections were destained in $96 \%$ boiling ethanol for $20 \mathrm{~min}$ and mounted on microscope slides in 50 $\%$ glycerol.

\section{ii) Detection of Hydrogen Peroxide $\left(\mathrm{H}_{2} \mathrm{O}_{2}\right)$}

Detection again followed the method of [41] with some modification. Traverse sections of the leaf stem were cut by hand free and deposited in Petri plates containing a solution of $5 \mathrm{mM}$ diaminobenzidine HCL (DAB), $\mathrm{pH} 3.8$ for $12 \mathrm{~h}$. Control samples were maintained in deionised water. All sections were destained in $96 \%$ boiling ethanol for $20 \mathrm{~min}$ and mounted on microscope slides in $50 \%$ glycerol.

\section{Phenolic Composition}

Analysis of total phenolic content used methanol as an extraction agent and Folin and Ciocalteu reagent to determine concentration [42].

To extract phenolics, $0.3 \mathrm{~g}$ of leaves were ground in liquid nitrogen and the powder resuspended in $4 \mathrm{ml} 50 \%$ methanol. The suspension was incubated at $80{ }^{\circ} \mathrm{C}$ for $1.5 \mathrm{~h}$ and then centrifuged at $12,000 \mathrm{rpm}$ for $15 \mathrm{~min}$. The supernatant was collected and analysed for free phenolics.
The pellet was resuspended in $2 \mathrm{ml} 0.5 \mathrm{M} \mathrm{NaOH}$ and incubated for $24 \mathrm{~h}$ for saponification of bound phenolics in the cell wall. The reaction was neutralised with $0.5 \mathrm{ml} 2 \mathrm{M}$ hydrochloric acid and the mixture centrifuged at 15,000 rpm for $15 \mathrm{~min}$. The supernatant was recovered.

To $150 \mu \mathrm{l}$ of supernatant (either free or bound phenolics) was added $3 \mathrm{ml}$ of $2 \%$ sodium carbonate and $150 \mu \mathrm{l}$ of Folin Ciocateu reagent (diluted 1:1 in water). Absorbance was read by spectrophotometer (Fento 482, USA) at $750 \mathrm{~nm}$. A standard curve was prepared using chlorogenic acid solutions and the concentration of phenolics was expressed as chlorogenic acid equivalents per $\mathrm{mg}$ of fresh tissue.

\section{Saccharose, Fructose and Total Carbohydrate Content}

Soluble sugars, fructose and saccharose were measured using the antrona reagent method [43].

\section{i) Preparation of Crude Extract}

One gram of leaves was immersed in $10 \mathrm{ml}$ of $80 \%$ ethanol for $3 \mathrm{~min}$ and then homogenised and incubated at $80^{\circ} \mathrm{C}$ in a water bath for $30 \mathrm{~min}$. After incubation samples were centrifuged at $10,000 \mathrm{rpm}$ for $10 \mathrm{~min}$. The supernatant was extracted and the process was repeated on the pellet two more times. After three ethanol extractions the supernatants were mixed and stored.

The pellet was resuspended in $15 \mathrm{ml}$ of water and this suspension was incubated at $60{ }^{\circ} \mathrm{C}$ in a water bath for $30 \mathrm{~min}$ and then centrifuged as above. The supernatant was removed and the process was repeated. The supernatants (ethanol and aqueous fractions) were mixed and placed in a rotoevaporator at $60{ }^{\circ} \mathrm{C}$ and a rotation speed of $7000 \mathrm{rpm}$ until reaching a volume of $5 \mathrm{ml}$. The crude extract (CE) was kept at $-20{ }^{\circ} \mathrm{C}$ until analysed.

\section{ii) Total Carbohydrate Content}

Total soluble carbohydrate content was determined using $50 \mu \mathrm{l}$ of CE, $200 \mu \mathrm{l}$ of water and $2.5 \mathrm{ml}$ of $0.2 \%$ antrona solution (76 ml sulphuric acid, $24 \mathrm{ml}$ water and $0.2 \mathrm{~g}$ antrona). The samples were incubated at $100{ }^{\circ} \mathrm{C}$ in a water bath for $10 \mathrm{~min}$ and then kept in darkness for $20 \mathrm{~min}$. Absorbance was measured at $620 \mathrm{~nm}$. The absorbance was compared to standard curve of glucose $(0.5,1.0,1.5$ and 2.0 $\left.\mathrm{mg} \mathrm{ml}^{-1}\right)$.

\section{iii) Fructose Content}

To $50 \mu 1$ of CE was added $250 \mu 1$ water and $2.5 \mathrm{ml} 0.2 \%$ antrona reagent. The samples were mixed using a vortexer and incubated at $37{ }^{\circ} \mathrm{C}$ for $45 \mathrm{~min}$. Absorbance was measured at $620 \mathrm{~nm}$ and compared at a glucose standard curve $\left(0.5\right.$ to $\left.2.0 \mathrm{mg} \mathrm{ml}^{-1}\right)$.

\section{iv) Saccharose Content}

To $100 \mu \mathrm{l}$ of crude extract was added $250 \mu \mathrm{l}$ water, 100 $\mu 15.4 \mathrm{M}$ potassium hydroxide and $3 \mathrm{ml} 0.2 \%$ antrona reagent. Absorbance was read at $620 \mathrm{~nm}$ and compared at a standard curve of saccharose ( 0.5 to $\left.2.0 \mathrm{mg} \mathrm{ml}^{-1}\right)$.

\section{Statistical Analysis}

Each experiment used three replicates, and was repeated on two further occasions. Comparisons were performed 
using an ANOVA, with Tukey test at 5\% probability for variation over time, or two way ANOVA for comparison of treatments.

\section{RESULTS}

\section{Peroxidase}

Sodium nitroprusside (SNP) increased peroxidase activity significantly after $120 \mathrm{~h}$ (Table 1). Application of yeast produced a similar, though slightly faster, increase in enzyme activity, significant after $72 \mathrm{~h}$.

On a shorter timescale after treatment with SNP an immediate increase in peroxidase activity was observed and this was sustained for $6 \mathrm{~h}$ (Fig. 1). Time points up to $6 \mathrm{~h}$ and time points beyond $6 \mathrm{~h}$ formed two groups statistically, significantly different to each other, but not within groups $(p<0.05)$, except for a secondary peak at $72 \mathrm{~h}$ which was not significantly different to either group. Peroxidase activity did not change significantly over this time course for either control or water treatments $(\mathrm{p}<0.05)$. Overall, peroxidase activity was significantly different in the SNP treated group compared to either control or water treatment $(p<0.001)$. It should be noted however that activity following water treatment was also significantly different to the control $(\mathrm{p}<0.001)$.

Peroxidase activity after $\mathrm{PMeV}$ inoculation formed two significantly different time point groups, before and after $6 \mathrm{~h}$ $(\mathrm{p}<0.05)$ (Fig. 2). Activity rose by approximately 10 fold after $6 \mathrm{~h}$ and this level was maintained for at least 30 days. A very similar pattern was found with $\mathrm{PMeV}$ inoculation concomitant with SNP treatment, although the $6 \mathrm{~h}$ time point was intermediate between the two groups. This is in contrast to the activity of peroxidase following treatment with SNP alone (Fig. 1), where the same $6 \mathrm{~h}$ cut off point was observed, but with a decrease rather than increase in activity.

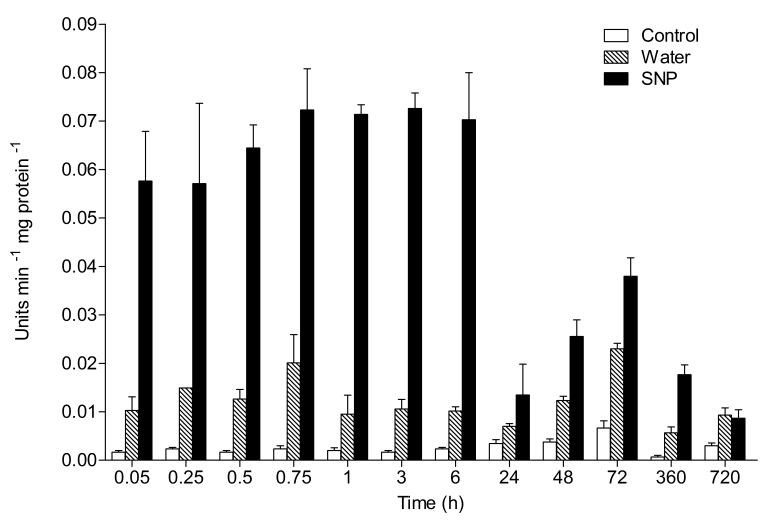

Fig. (1). Peroxidase (POD) activity after treatment with SNP. Time after treatment represented b letters, (A) $3 \mathrm{~min}$; (B) $15 \mathrm{~min}$; (C) 30 min; (D) 45 min; (E) 1 h; (F) 3 h; (G) 6 h; (H) 24 h; (I) 48 h; (J) 72 h; (K) 15 days; (L) 30 days. The bars represent standard error of three replicates. Controls (white), treatment with water alone (grey), treatment with SNP (black).

To determine the location of peroxidase activity increase, histochemical studies were undertaken. Histochemical staining of transverse leaf stem sections for hydrogen peroxide showed differences in intensity between treated and untreated plants (Fig. 3). Staining was more intense in SNP treated plants, especially in the phloem (Fig. $\mathbf{3 b}, \mathbf{d}, \mathbf{f}, \mathbf{j}, \mathbf{l}$ ), and was more intense over the first hour. Differences in intensity of staining were observed over six $h$.

Table 1. Peroxidase Activity and Mean Concentration of Free and Bound Phenolics after Treatment with Water, SNP or Yeast Extract

\begin{tabular}{|c|c|c|c|c|}
\hline \multirow{2}{*}{ Time (hr) } & \multirow{2}{*}{ Treatment } & \multirow{2}{*}{ Peroxidase Activity (abs $\min ^{-1} \mathrm{~g}^{-1}$ Fresh Tissue) } & \multicolumn{2}{|c|}{ Phenolics (mg g ${ }^{-1}$ Fresh Tissue) } \\
\hline & & & Free & Bound \\
\hline \multirow{3}{*}{0} & Water & $0.187+/-0.033 \mathrm{a}$ & $157.5+/-1.4 \mathrm{a}$ & $120.3+/-2.5 \mathrm{a}$ \\
\hline & SNP & $0.217+/-0.017 \mathrm{a}$ & $167.2+/-1.7 \mathrm{a}$ & $129.5+/-2.8 \mathrm{a}$ \\
\hline & Yeast & $0.255+/-0.059 a$ & $164.6+/-2.7 \mathrm{a}$ & $133.6+/-2.4 a$ \\
\hline \multirow{3}{*}{72} & Water & $0.173+/-0.064 \mathrm{a}$ & $137.9+/-11.0 \mathrm{a}$ & $119.5+/-2.8 \mathrm{a}$ \\
\hline & SNP & $0.398+/-0.034 \mathrm{a}$ & $225.5+/-12.5 b$ & $126.3+/-4.5 \mathrm{a}$ \\
\hline & Yeast & $0.561+/-0.096 \mathrm{~b}$ & $191.9+/-12.7 \mathrm{~b}$ & $161.2+/-5.2 b$ \\
\hline \multirow{3}{*}{120} & Water & $0.410+/-0.069 \mathrm{a}$ & $160.3+/-6.7 \mathrm{a}$ & $116.5+/-4.0 \mathrm{a}$ \\
\hline & SNP & $0.786+/-0.041 b$ & $214.0+/-7.4 b$ & $127.1+/-4.9 \mathrm{a}$ \\
\hline & Yeast & $1.080+/-0.182 \mathrm{~b}$ & $199.4+/-11.8 b$ & $141.2+/-1.8 b$ \\
\hline \multirow{3}{*}{168} & Water & $0.305+/-0.074 \mathrm{a}$ & $123.6+/-4.3 \mathrm{a}$ & $127.2+/-4.4 \mathrm{a}$ \\
\hline & SNP & $0.839+/-0.067 \mathrm{~b}$ & $215.6+/-6.4 b$ & $137.1+/-6.8 \mathrm{a}$ \\
\hline & Yeast & $1.426+/-0.093 \mathrm{~b}$ & $133.8+/-10.4 \mathrm{a}$ & $140.9+/-4.1 \mathrm{a}$ \\
\hline
\end{tabular}

Within each vertical group of three measurements (Water, SNP, Yeast) numbers with the same letter are not significantly different by Tukey test (5\% level of probability). 


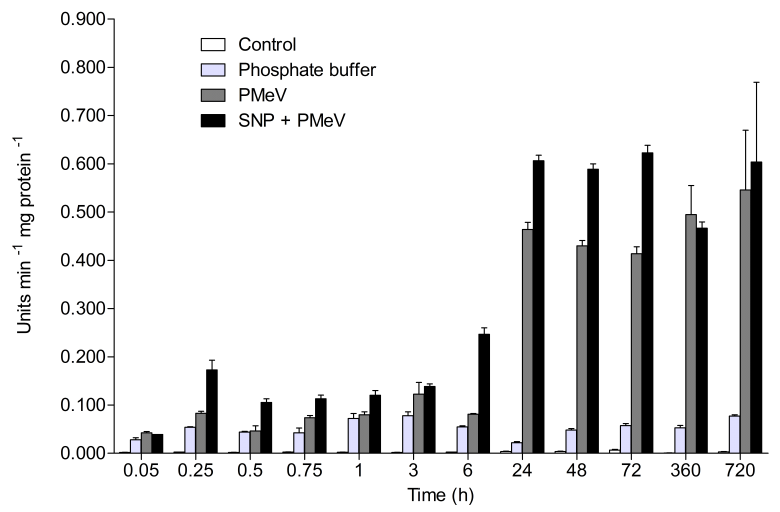

Fig. (2). Peroxidase (POD) activity after treatment with $\mathrm{PMeV}$ or SNP. Time after treatment represented by letters, (A) 3 min; (B) 15 min; (C) 30 min; (D) 45 min; (E) 1 h; (F) 3 h; (G) 6 h; (H) 24 h; (I) 48 h; (J) 72 h; (K) 15 days; (L) 30 days. The bars represent standard error of three replicates. Controls (white), injection with phosphate buffer (light grey), injection with $\mathrm{PMeV}$ (dark grey), injection with PMeV and SNP treatment (black).

\section{Superoxide Dismutase}

Treatment with the NO donor sodium nitroprusside (SNP) led to an increase in SOD enzyme activity. Enzyme activity peaked almost immediately after treatment and maintained a high level up to 30 days post-treatment (Fig. 4). There was however variation in activity during the time course of the experiment, and significant difference between time points $(p<0.05)$, although no clear pattern could be discerned. In neither control nor water treatments was a significant change in SOD activity observed over time $(\mathrm{p}<0.05)$.

Overall, SOD activity was considerably higher following SNP treatment compared to water or control treatments and was significantly different to both $(p<0.001)$. As with peroxidase activity, it should be noted that SOD activity was also significantly different between water treated and control groups over this time course $(\mathrm{p}<0.001)$.

To discern the effect of $\mathrm{PMeV}$ on superoxide dismutase activity plants were treated with both virus and NO. Overall, PMeV inoculation with or without SNP increased SOD expression (Fig. 5). SOD activity following PMeV treatment alone did not change significantly over time after the initial peak $(p<0.05)$, and overall activity was significantly different to all other groups, being greater than the controls or phosphate buffer treated group, but less than $\mathrm{PMeV}$ with SNP $(p<0.001)$. Indeed, all four treatment groups were significantly different to each other over the 30 days of the experiment $(\mathrm{p}<0.001)$. SOD activity following PMeV with SNP was the highest measured at each time point, and was significantly different from each treatment overall $(\mathrm{p}<0.001)$. However, considerable variation was observed over time, with a trend towards decrease of activity towards the end of the time course. An increase in SOD enzyme activity was observed at all time points from simple injection of phosphate buffer alone, compared to the control, suggesting that mechanical injury triggered a response (Fig. 5).

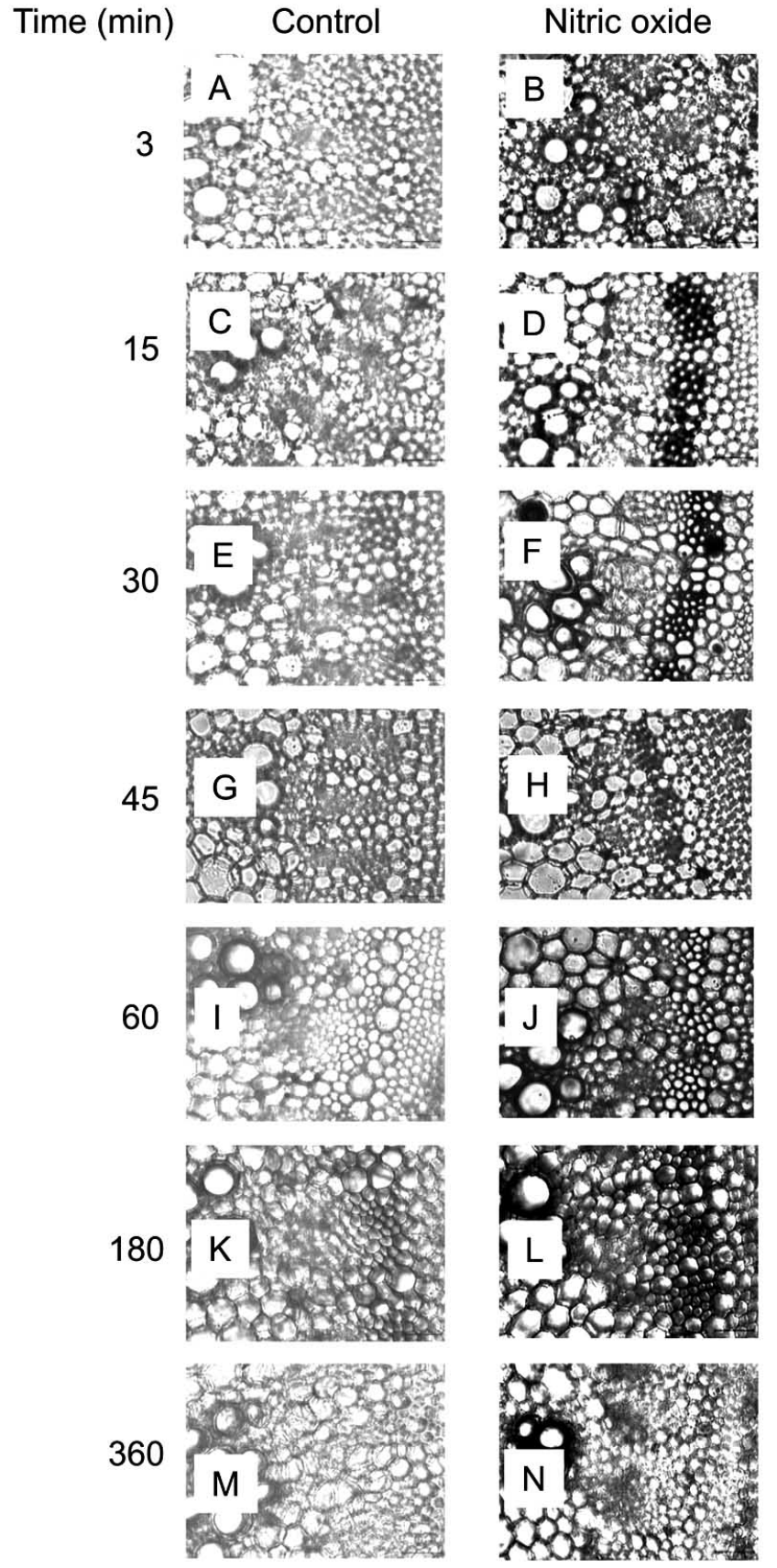

Fig. (3). Histochemistry of transverse sections of leaf stem after treatment with SNP. Stained with diaminobenzidine $\mathrm{HCl}$ (DAB). Time post treatment represented by letter. Pictures A, C, E, G, I, K \& $\mathbf{M}$ represent control, water treated, plants at times 3, 15, 30, 45, 60, 180 and 360 min after treatment respectively, while B, D, F, H, $\mathbf{J}, \mathbf{L} \& \mathbf{N}$ represent plants treated with SNP at the same times. Bar = $100 \mu \mathrm{m}$.

To identify the area of the leaf in which SOD enzyme activity takes place, leaves were analyzed for formation of superoxide radicals using histochemistry. Radicals appeared to be located mostly in the phloem and xylem, with lesser activity in the epidermis and subepidermis (Fig. 6d, h, i). 


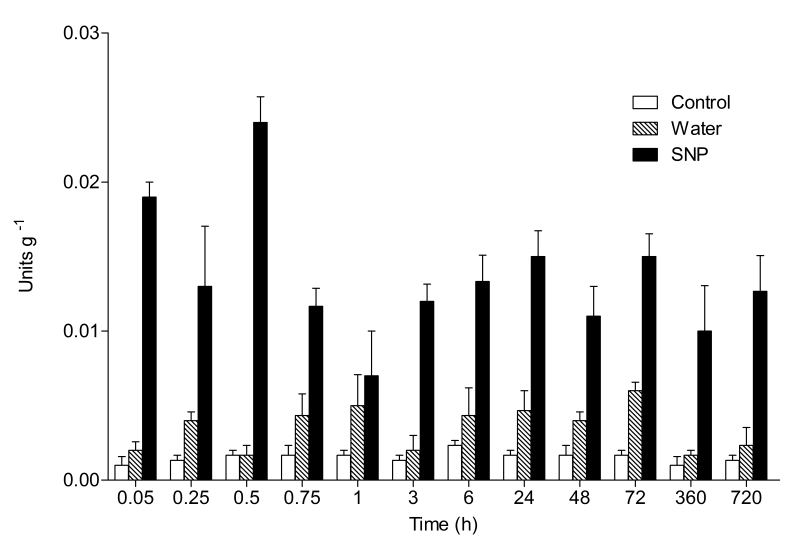

Fig. (4). Activity of superoxide dismutase after treatment with SNP. Cultivar Golden. Time points represented by letters, (A) $3 \mathrm{~min}$, (B) $15 \mathrm{~min}$, (C) $30 \mathrm{~min}$, (D) $45 \mathrm{~min}$, (E) $1 \mathrm{~h}$, (F) $3 \mathrm{~h}$, (G) $6 \mathrm{~h}$, (H) $24 \mathrm{~h}$, (I) 48 h, (J) 72 h, (K) 15 days, (L) 30 days. Bars represent standard error after 3 replicates. White columns are controls, grey are seedlings treated with water, and black are seedlings treated with SNP.

Sizeable differences were observed in the intensity of staining, being consistently greater in plants treated with SNP (Fig. 6a,c,e). A relationship was observed between histochemistry and enzymatic activity. This is illustrated by the histochemistry $30 \mathrm{~min}$ after SNP treatment (Fig. 6f), in which dark staining for superoxide in the area of xylem and phloem corresponds to a peak in SOD activity.

\section{Phenolics}

NO increased the titre of free phenolics at all time points, increasing by 63,36 and $74 \%$ over controls after 72, 120 and $168 \mathrm{~h}$ respectively (Table 1). There was no significant change in the level of bound phenolics.

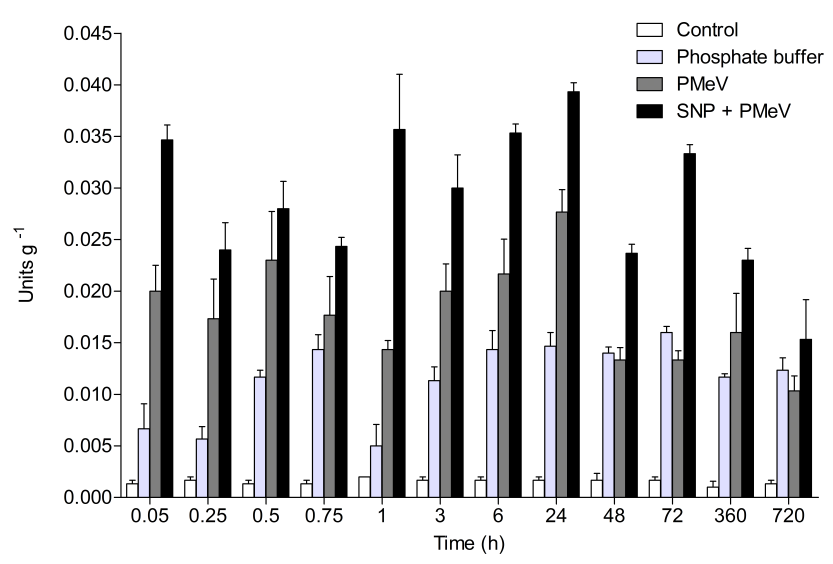

Fig. (5). Activity of superoxide dismutase (SOD) at various times post treatment with $\mathrm{PMeV}$ or SNP. Times represented by letters. (A) $3 \mathrm{~min}$; (B) $15 \mathrm{~min}$; (C) $30 \mathrm{~min}$; (D) $45 \mathrm{~min}$; (E) $1 \mathrm{~h}$; (F) $3 \mathrm{~h}$; (G) $6 \mathrm{~h}$; (H) $24 \mathrm{~h}$; (I) $48 \mathrm{~h}$; (J) $72 \mathrm{~h}$; (K) 15 days (L) 30 days. Bars represent standard errors of three replicates. Treatments represented by colours. White (control), light grey (injection with phosphate buffer), dark grey (injection with $\mathrm{PMeV}$ ) and black (SNP + PMeV injection).
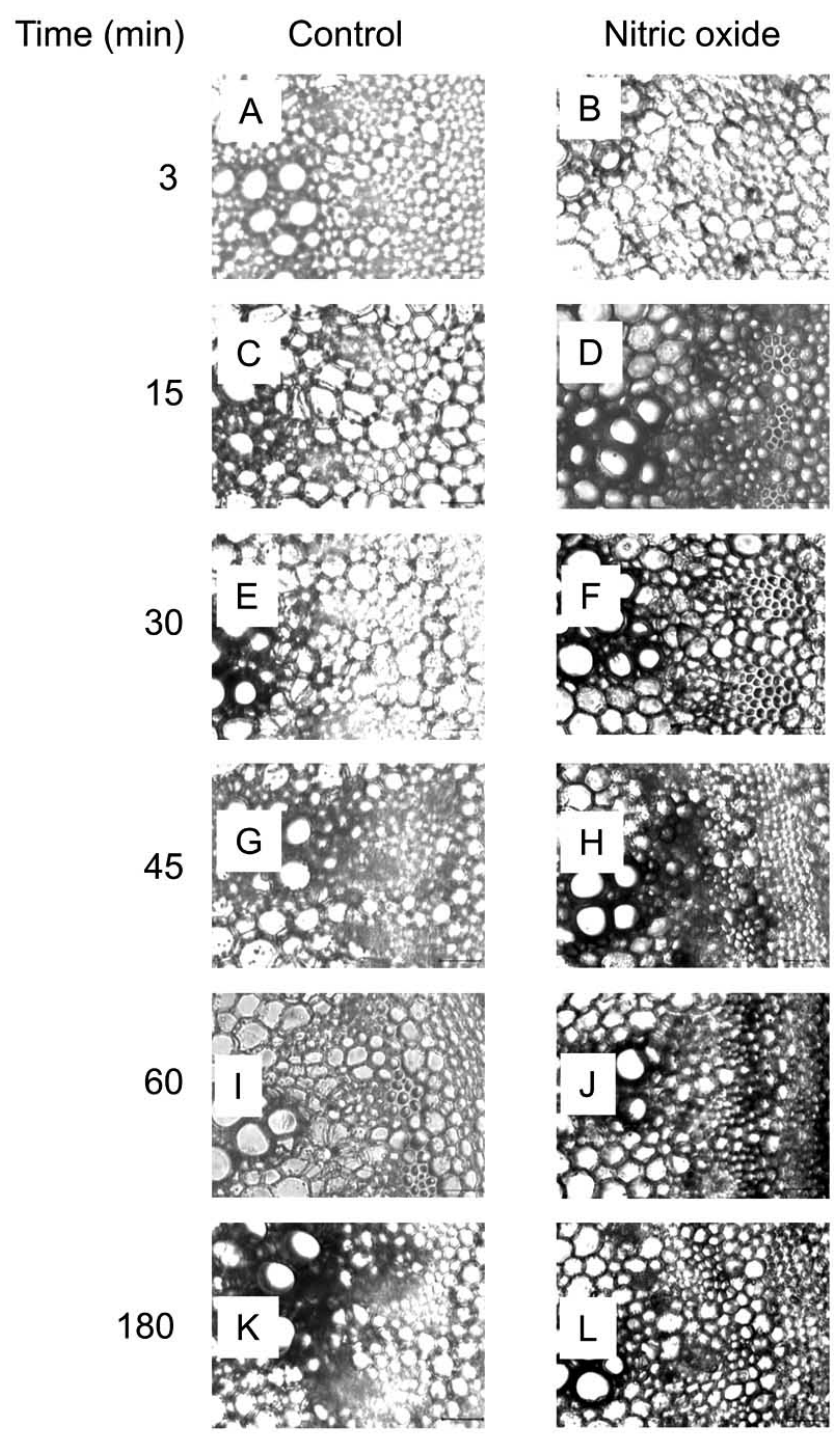

360
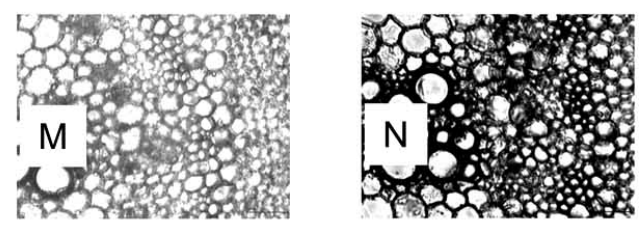

Fig. (6). Microscopy of transverse sections of leaf stem of papaya, cv. Golden following treatment with SNP. Stained with nitroblue tetrazolium. Pictures A, C, E, G, I, K \& $\mathbf{M}$ represent control, water treated, plants at times $3,15,30,45,60,180$ and $360 \mathrm{~min}$ after treatment respectively. Pictures $\mathbf{B}, \mathbf{D}, \mathbf{F}, \mathbf{H}, \mathbf{J}, \mathbf{L}, \& \mathbf{N}$ represent plants treated with SNP at the same time periods. Bar $=100 \mu \mathrm{m}$.

The greatest difference between yeast treatment and controls was recorded $72 \mathrm{hrs}$ after treatment (Table 1). The concentration of free phenolics after $72 \mathrm{hrs}$ was $39 \%$ greater than the control, whilst the level of bound phenolics was $35 \%$ greater. Both phenolic types were not significantly different to control levels after $168 \mathrm{hrs}$. 


\section{Concentration of Carbohydrates}

Addition of SNP did not have a significant effect on total carbohydrate levels or fructose, but saccharose content was significantly higher after 24 and 48 h (Table 2).

Total carbohydrate content increased significantly $24 \mathrm{~h}$ after treatment with yeast but by $48 \mathrm{~h}$ was not significantly different to the control. Fructose content did not change, but saccharose content increased significantly after $24 \mathrm{~h}$ and was maintained until at least $48 \mathrm{~h}$.

\section{DISCUSSION}

Papaya meleira virus $(\mathrm{PMeV})$ is a significant disease of the important crop papaya (Carica papaya). To investigate a reported involvement of nitric oxide (NO) in plant defence signalling we challenged papaya seedlings with a NO donor sodium nitroprusside (SNP), PMeV, and a model fungus (Saccharomyces cerevisiae). The responses of peroxidases, superoxide dismutases, phenolics and carbohydrates were determined. Treatments using SNP and yeast took the form of a spray and so it was considered necessary to include controls of both untreated and water treated plants. Mechanical perturbation has been shown to increase peroxidase activity in plants [44] and water spraying can change expression of some genes in $C$. papaya [35]. We found significant increases in peroxidase and superoxide dismutase activities in water sprayed plants compared to those without treatment, suggesting that both these enzymes respond to thigmonastic stress in C. papaya.

Peroxidases, together with catalases, are the major $\mathrm{H}_{2} \mathrm{O}_{2}$ degrading enzymes in plant cells [16]. We observed peroxidase activity to increase following addition of both yeast and PMeV to Carica papaya. Peroxidase activity after $\mathrm{PMeV}$ inoculation, with or without SNP, formed two significantly different time point groups, increasing by approximately 10 fold after $6 \mathrm{~h}$ and this level was maintained for at least 30 days. A similar increase was found following yeast exposure with an increase in activity found from 3 until at least 7 days. This is in contrast to the activity of peroxidase following treatment with the nitric oxide donor (SNP) alone, where the same $6 \mathrm{~h}$ cut off point was observed, but with a decrease rather than increase in activity although levels remained higher than the control. This suggests that NO can induce an increase in activity, but continued high enzyme activity is dependent on the presence of a pathogen.

Several authors have found a relationship between peroxidase levels and resistance to disease and it has been known for some time that a combination of peroxidases and hydrogen peroxide can be fatal to fungi [18]. Peroxidase activity is increased in plants infected with fungus [20], and peroxidase levels in maize rose faster post infection in varieties of maize resistant to Exserohilum turcicum [19]. Increase in peroxidase activity is also a response to viral infection, and has been reported in tobacco [45], peaches and apricots [21] and beans [22]. The relationship of NO to oxidative stress is complex. Beyond an effect on cell signalling, nitric oxide can cause direct oxidative damage by reacting with superoxide $\left(\mathrm{O}_{2}^{-}\right)$to form peroxynitrite $\left(\mathrm{ONOO}^{-}\right)$, a powerful oxidant which can react with DNA, lipids and proteins under physiological conditions, leading to cellular damage and cytotoxity [46]. Conversely, NO can also act as an antioxidant [47]. The effect of NO in any given circumstances appears to depend to some extent on the cellular ratio to reactive oxygen species (ROS) especially in terms of apoptosis [10]. It is in this matrix that the patterns of peroxidase activity we observed following SNP application to $C$. papaya with or without $\mathrm{PMeV}$, of an initial surge followed by a considerable decrease or increase in activity after $6 \mathrm{~h}$, need to be seen. The secondary increase after $6 \mathrm{hrs}$ is similar to the time scale found by [48] for an increase in gene expression in soybean plants following infection with Phytophthora sojae, which suggests that the pathogen related increase after $6 \mathrm{hrs}$ can be attributed to new gene expression.

Another class of antioxidant enzymes, superoxide dismutases (SODs) were also investigated. SODs are a group of metalloenzymes that catalyse the dismutation of superoxide radicals $\left(\mathrm{O}_{2}^{-}\right)$to $\mathrm{H}_{2} \mathrm{O}_{2}$ and $\mathrm{O}_{2}$ [49]. Treatment

Table 2. Mean Concentration of Total Carbohydrates, Fructose and Saccharose in Cultivar Golden treated with Water, SNP and Yeast Extract

\begin{tabular}{|c|c|c|c|c|}
\hline Time (hr) & Treatment & Total Carbohydrate ( $\mathrm{mg} \mathrm{g}^{-1}$ Fresh Tissue) & Fructose ( $\mathrm{mg} \mathrm{g}^{-1}$ Fresh Tissue) & Saccharose ( $\mathrm{mg} \mathrm{g}^{-1}$ Fresh Tissue) \\
\hline \multirow[t]{3}{*}{0} & Water & $0.115+/-0.006 \mathrm{a}$ & $0.042+/-0.002 \mathrm{a}$ & $0.044+/-0.002 \mathrm{a}$ \\
\hline & SNP & $0.109+/-0.004 \mathrm{a}$ & $0.044+/-0.002 \mathrm{a}$ & $0.041+/-0.002 \mathrm{a}$ \\
\hline & Yeast & $0.107+/-0.011 \mathrm{a}$ & $0.045+/-0.002 \mathrm{a}$ & $0.044+/-0.003 \mathrm{a}$ \\
\hline \multirow[t]{3}{*}{24} & Water & $0.112+/-0.007 \mathrm{a}$ & $0.045+/-0.002 \mathrm{a}$ & $0.046+/-0.004 \mathrm{c}$ \\
\hline & SNP & $0.144+/-0.012 \mathrm{ab}$ & $0.045+/-0.002 \mathrm{a}$ & $0.068+/-0.002 b$ \\
\hline & Yeast & $0.167+/-0.005 \mathrm{~b}$ & $0.055+/-0.002 \mathrm{a}$ & $0.087+/-0.003 \mathrm{a}$ \\
\hline \multirow[t]{3}{*}{48} & Water & $0.131+/-0.009 \mathrm{a}$ & $0.046+/-0.002 \mathrm{a}$ & $0.056+/-0.005 b$ \\
\hline & SNP & $0.166+/-0.020 \mathrm{a}$ & $0.046+/-0.002 \mathrm{a}$ & $0.071+/-0.003 \mathrm{a}$ \\
\hline & Yeast & $0.138+/-0.009 a$ & $0.042+/-0.002 \mathrm{a}$ & $0.081+/-0.003 \mathrm{a}$ \\
\hline
\end{tabular}

Within each vertical group of three measurements (Water, SNP, Yeast) numbers with the same letter are not significantly different by Tukey test (5\% level of probability). 
with SNP led to an increase in total SOD enzyme activity, peaking almost immediately after treatment and remaining at a high level for up to 30 days post treatment, whilst no change was observed in controls or water treated. $(p<0.05)$. Overall, PMeV inoculation also increased SOD activity and did not change significantly over time after the initial peak. SOD activity following PMeV with SNP was the highest measured at each time point, and was significantly different from each treatment overall $(p<0.05)$. This is consistent with previous reports that show that virus infection can induce SOD activity [50,51].

To identify the area of the leaf in which SOD enzyme activity takes place following NO exposure, leaves were analyzed for formation of superoxide radicals using histochemistry. Activity appeared to be located mostly in the phloem and xylem, with lesser activity in the epidermis and subepidermis and was consistently greater in plants treated with SNP. A relationship was observed between histochemistry and measured enzymatic activity. Recently a role for SOD in the regulation of $\mathrm{H}_{2} \mathrm{O}_{2}$ has been described [52] and thus SOD activity at the cell walls may be related to lignification.

Phenolics are an important part of plant defences against fungi and bacteria [30]. Although papaya fruit have a relatively low level of phenolics compared to other fruit [53], we observed a significant response. Levels of free phenolics were elevated in response to NO challenge, but bound phenolics were not significantly altered. Both free and bound phenolics were elevated after 72 and $120 \mathrm{~h}$ in response to yeast. An increase in phenolic levels in response to a fungal elicitation was expected from previous studies [54,55]. Plant phenolics are also effective against viruses, and are induced by virus infection [33] which has led to a number of studies of the possibility of their use against human viruses (reviewed in [56]. It is therefore interesting in the context of $\mathrm{PMeV}$ that SNP increased phenolic levels in papaya. Phenolics can also be potent antioxidants [57] and so it is unclear whether a rise in phenolic levels in response to NO would be an antioxidant defence, or the result of NO signalling of another challenge such as viral infection. Of course the two are not incompatible.

Another important involvement of phenolics with resistance is in the formation of lignin, in conjunction with peroxidases, to create a physical barrier to limit fungus $[58,59]$ or virus [21] invasion. This also renders the wall more water resistant and thus less accessible to cell walldegrading enzymes [60]. Carica papaya has an intermediate numbers of lignin synthetic genes, fewer than poplar, but more than A. thaliana [61]. Histochemical staining of transverse leaf stem sections for hydrogen peroxide showed differences in intensity between control plants and those treated with the NO donor SNP. Staining was more intense in SNP treated plants, especially in the phloem and was more intense over the first hour with activity maintained for at least $6 \mathrm{~h}$. It has been reported that class III peroxidases, those involved in lignification, are concentrated in the cell wall [62], and so this, like the elevated SOD levels described above, would be consistent with an increase in lignification in response to nitric oxide.
We observed a significant increase in saccharose content after yeast inoculation, and a more transient increase in total carbohydrate content. This is in accordance with other studies which have found increases in carbohydrate titres to be a general plant response to stress [23] and fungal infection [25]. Regarding viruses, carbohydrates appear to have a role in plant defences, and it has been known since the 1930s that accumulation of starch precedes the presence of virus symptoms [24] and, for example, marrows infected with Zucchini yellow mosaic virus show increased sucrose titres [26]. Following SNP treatment we also observed a significant increase in saccharose content, and a more transient increase in total carbohydrate content. A link of carbohydrates with defences against oxidative stress has been observed in other studies $[27,28]$ and carbohydrates are essential in the production of many anti-oxidant defences ([29].

It has been known for some time that plants can acquire a long term systemic immunity to the original, and other, pathogens, known as Systemic acquired resistance (SAR) [63]. It has been known since the 1960s that viruses are SAR inducers [64] and that resistance to viruses can be induced $[33,65]$. The potential applicability of this technique to papaya has already been shown using acibenzolar-S-methyl as an inducer [64]. We examined the response of various biological parameters in response to yeast and $\mathrm{PMeV}$ inoculation. Application of yeast led to enhanced peroxidase activity in the plants for at least 7 days, whilst we found that injection of the virus $\mathrm{PMeV}$ enhanced peroxidase activity for over 30 days. This activity was especially strong in the cells wall, and is presumably associated with increased lignification. These results would appear to suggest that long lasting defence responses can in deed be induced by pathogens in Carica papaya, including PMeV.

\section{CONCLUSIONS}

Induction of resistance to $\mathrm{PMeV}$ in Carica papaya would appear to present an attractive opportunity for disease control, given the lack of resistant varieties available. Systemic resistance has already been successfully induced in other plants against viruses, and because no transgenic techniques are employed it should be more commercially acceptable. However, it should be borne in mind that some concern has been expressed about the applicability of induced resistance in the field compared to the laboratory or glasshouse, as plants may already be at or near their limit from pre-existing stresses [67,68]. Another consideration is that the applicability of this technique is likely to be cultivar dependent, as has been found in tomatoes [69].

There appears to be an important role for $\mathrm{NO}$ in defence induction in C. papaya, as the NO donor SNP not only induced a long lasting (30 day) increase in peroxidase titre, but also the production of both phenolics and carbohydrates, both of which are antioxidant defences and important in plant defence against viruses. Additionally a rise in both bound phenolics and wall-associated peroxidases was observed following SNP addition which was still evident 7 days after treatment, suggesting an increase in wall lignification, another viral defence. An involvement of NO in the SAR response appears to be supported by the 
literature. When tobacco plants are treated on one leaf with NO donors, the whole plant develops enhanced resistance to TMV up to 13 days later, whilst addition of NOS inhibitors reduces considerably tobacco SAR [70].

Many plant diseases, especially viruses, have no cure as yet. Induction of natural plant resistance has potential to fill this gap, and the involvement of NO in this process appears to be critical, although further work is needed to completely establish the pathways involved in the response.

\section{LIST OF ABBREVIATIONS}

$\begin{array}{lll}\mathrm{H}_{2} \mathrm{O}_{2} & = & \text { Hydrogen peroxide } \\ \mathrm{HR} & = & \text { Hypersensitive response } \\ \mathrm{NO} & = & \text { Nitric oxide } \\ \mathrm{PMeV} & = & \text { Papaya meleira virus } \\ \mathrm{ROS} & = & \text { Reactive oxygen species } \\ \mathrm{SNP} & = & \text { Sodium nitroprusside } \\ \mathrm{SOD} & = & \text { Superoxide dismutase }\end{array}$

\section{ACKNOWLEDGEMENTS}

The authors acknowledge the financial support provided by CAPES (Coordenação de Aperfeiçoamento de Pessoal de Nível Superior, Brazil), FAPES (Fundação de Amparo a Pesquisa do Espírito Santo) and CNPq (Conselho Nacional de Pesquisa, Brazil).

\section{CONFLICT OF INTEREST}

None declared.

\section{REFERENCES}

[1] Gouado, I.; Schweigert, F.J.; Ejoh, R.A.; Tchouanguep, M.F.; Camp, J.V. Systemic levels of carotenoids from mangoes and papaya consumed in three forms juice fresh and dry slice. Eur. J. Clin. Nutr., 2007, 61, 1180-1188.

[2] Tecson Mendoza, E.M.; Laurena, A.; Botella, J.R. Recent advances in the development of transgenic papaya technology. Biotechnol. Annu. Rev., 2008, 14, 423-462.

[3] Zambolim, E.M.; Alonso, S.K.; Matsoka, K.; Carvalho, M.G.; Zerbini, F.M. Purification and some properties of Papaya meleira virus a novel virus infecting papayas in Brazil. Plant Pathol., 2003, 52, 389-394.

[4] Kitajima, E.W.; Rodriguez, C.H.; Silveram, J.A.; Alves, F.L.; Ventura, J.A.; Aragao, F.J.L.; Olivera, L.H.R. Association of isometric particles restricted to laticifers with meleira (sticky disease) of papaya (Carica papaya). Fitopatol. Bras., 1993, 18, 118-122.

[5] Rodrigues, S.P.; Da Cunha, M.; Ventura, J.A.; Fernandes, P.M.B. Effects of the Papaya meleira virus on papaya latex structure and composition. Plant Cell Rep., 2009, 28, 861-871.

[6] Rodrigues, S.P.; Galvão, O.P.; Andrade, J.S.; Ventura, J.A. Fernandes, P.M.B. Simple molecular method to papaya sticky disease detection from latex and tissues samples. Summa Phytopatol, 2005, 31, 273-275.

[7] Greenberg, J.T.; Yao, N. The role and regulation of programmed cell death in plant-pathogen interactions. Cell Microbiol., 2004, 6, 201-211.

[8] Delledonne M,; Zeier J,; Marocco A,; Lamb C. Signal interactions between nitric oxide and reactive oxygen intermediates in the plant hypersensitive disease resistance response. Proc. Natl. Acad. Sci. USA, 2001, 98, 13454-13459.

[9] Tada, Y.; Mori, T.; Shinogi, T. Nitric oxide and reactive oxygen species do not elicit hypersensitive cell death but induce apoptosis in the adjacent cells during the defence response of oat. Mol. Plant Microbe Interact., 2004, 17, 245-253.

[10] Delledonne, M.; Xia, Y.; Dixon, R.A.; Lamb C. Nitric oxide functions as a signal in plant disease resistance. Nature, 1998, 394, 585-588.
[11] Durner, J.; Wendehenne, D.; Klessig, D.F. Defense gene induction in tobacco by nitric oxide cyclic GMP and cyclic ADP-ribose. Proc. Natl. Acad. Sci. USA, 1998, 95, 10328-10333.

[12] Saito, S.; Yamamoto-Katou, A.; Yoshioka, H.; Doke, N.; Kawakita, K. Peroxynitrite generation and tyrosine nitration in defense responses in tobacco BY-2 cells. Plant Cell Physiol., 2006, 47, 689-697.

[13] Tanou G.; Molassiotis, A.; Diamantidis, G. Hydrogen peroxide- and nitric oxide-induced systemic antioxidant prime-like activity under $\mathrm{NaCl}-$ stress and stress-free conditions in citrus plants. J. Plant Physiol., 2009, 166, 1904-1913.

[14] Stamler, J.S.; Lamas, S.; Fang, F.C. Nitrosylation the prototypic redoxbased signalling mechanism. Cell, 2001, 106, 675-683.

[15] Wang, Y.; Yun, B.W.; Kwon, E.J.; Hong, J.K.; Yoon, J.Y.; Loake, G.J. S-nitrosylation: an emerging redox-based post-translational modification in plants. J. Exp. Bot., 2006. 57, 1777-1784.

[16] Durner, J.; Klessig, D.F. Inhibition of ascorbate peroxidase by salicylic acid and 26-dichloroisonicotinic acid two inducers of plant defense responses. Proc. Natl. Acad. Sci. USA, 1995, 92, 11312-11316.

[17] Kim, K.K.; Fravel, D.R.; Papavizas, G.C. Identification of a metabolite produced by Talaronzyces flavus as glucose oxidase and its role in the biocontrol of Verticillium dahliae. Phytopathol, 1988, 78, 488-492.

[18] Lehrer, R.I. Antifungal effects of peroxidase systems. J. Bacteriol., 1969, 99, 361-365.

[19] Shimoni, M.; Bar-Zur, A.; Reuveni B. The association of peroxidase activity and resistance of maize to Exserobilum triticum. J. Phytopathol. 1991, 131, 315-321.

[20] Dalisay, R.F.; Kuc, J.A. Persistence of reduced penetration by Colletotrichum lagenarium into cucumber leaves with induced systemic resistance and its relation to enhanced peroxidase and chitinase activities. Physiol Mol Plant Pathol., 1995, 47: 329-338.

[21] Diaz-Vivancos, P.; Rubio, M.; Mesonero, V.; Periago, P.M.; Ros Barcelo, A. Martınez-Gomez, P.; Hernandez, J.A. The apoplastic antioxidant system in Prunus: response to long-term plum pox virus infection. J. Exp. Bot. 2006, 57, 3813-3824.

[22] Radwan, D.E.M.; Fayez, K.A.; Mahmoud, S.Y.; Lu, G. Modifications of antioxidant activity and protein composition of bean leaf due to Bean yellow mosaic virus infection and salicylic acid treatments. Acta Physiol. Plant, 2010, 32, 891-904.

[23] Roitsch, T. Source-sink regulation by sugar and stress. Curr. Opin. Plant Biol., 1999, 2, 198-206.

[24] Holmes. F. Local lesions of mosaic in Nicotiana tabacum L. Contr. Boyce Thompson Inst., 1931, 3, 163.

[25] Orchard, J.E.; Hardwick, K. Photosynthesis carbohydrate translocation and metabolism of host and fungal tissues in cacao seedlings infected with Crinipellis pemiciosa. In: Proceedings of the 10th International Cocoa Research Conference Santo Domingo Lagos Nigeria: Cocoa Producers Alliance, 1988, pp. 325-30.

[26] Blua, M.J.; Perring, T.M.; Madore, M.A. Plant virus-induced changes in aphid population development and temporal fluctuations in plant nutrients. J. Chem. Ecol., 1994, 20, pp. 691-707.

[27] Sulmon, C.; Gouesbet, G.; Coue'e, I.; El Amrani, A. Sugar induced tolerance to atrazine in Arabidopsis seedlings: interacting effects of atrazine and soluble sugars on psbA mRNA and D1 protein levels. Plant Sci. 2004, 167, 913-923.

[28] Loreti, E.; Poggi, A.; Novi, G.; Alpi, A.; Perata, P. A genome-wide analysis of the effects of sucrose on gene expression in Arabidopsis seedlings under anoxia. Plant Physiol., 2005, 137, 1130-138.

[29] Couée Sulmon, C.; Gouesbet, G.; Amrani, A.E. Involvement of soluble sugars in reactive oxygen species balance and responses to oxidative stress in plants. J. Exp. Bot., 2006, 57, 449-459.

[30] Friend, J. Alterations in Secondary Metabolism. In:. Effects of disease on the physiology of the growing plant. Ayres, P.G., Ed; Cambridge New York Cambridge University Press. 1981, pp.179-200.

[31] Wulff, N.A.; Paschioti, S.F. Preparações de Saccharomyces cerevisiae elicitoras dev fitoalexinas em mesocótilos de sorgo. Scientia Agrícola Piracicaba, 1998, 55, 138-143.

[32] Scarpari, L.M.; Methardt, L.W.; Pomela, A.W.; Schivianato,A.; Mazzaferra, P.; Cascardo, J.M.; Pereira, G.A.G. Biochemical change during the development of witches broom: the most important disease of cocoa in Brazil caused by Crinipellis perniciosa. J. Exp. Bot., 2005, $56,865-867$.

[33] Sudhakar, N.; Nagendra-Prasada, D.; Mohan, N.; Murugesan, K. A bench-scale cost effective and simple method to elicit Lycopersicon esculentum cv PKM1 tomato plants against Cucumber mosaic virus attack using ozone-mediated inactivated Cucumber mosaic virus inoculum. J. Virol. Methods, 2007, 146, 165-171. 
[34] Hassan Khan, M.T.; Ather, A. Potentials of phenolic molecules of natural origin and their derivatives as anti-HIV agents. Biotechnol Annu Rev., 2007, 13, 223-264.

[35] Porter B.W.; Zhu Y.J.; Webb D. T.; Christopher, D.A. Novel thigmomorphogenetic responses in Carica papaya: touch decreases anthocyanin levels and stimulates petiole cork outgrowths. Ann. Bot., 2009, 103, 847-858.

[36] Ederli, L.; Reale, L.; Madeo, L.; Ferranti, F.; Gehring, C.; Fornaciari, M.; Romanom B.; Pasqualini, S. NO release by nitric oxide donors in vitro and in planta. Plant Physiol. Biochem., 2009, 47, 42-48.

[37] Floryszak-Wieczorek, J.; Milczarek, G.; Arasimowicz, M.; Ciszewski, A. Do nitric oxide donors mimic endogenous NO-related response in plants? Planta, 2006, 224, 1363-1372.

[38] Lowry, O.H.; Rosebrough, N.J.; Farr, A.L.; Randall, R.J. Protein measurement with the folin phenol reagent. J. Biol. Chem., 1951, 193, 265-275.

[39] Roncato, M.C.; Pascholati, S.F. Alterações na atividade e no perfil eletroforético da peroxidase em folhas de milho Zea mays e sorgo Sorghum bicolor tratadas com levedura Saccharomyces cereviseae. Scientia Agrícola, 1998, 55, 395-402.

[40] Osswald, W.F.; Kraus, R.; Hippeli, S.; Benz, B.; Volpert, R.; Elstner, E.F. Comparison of the enzymatic activities of dehydroascorbic acid reductase glutathione reductase catalase peroxidase and superoxide dismutase of healthy and damaged spruce needles Picea abies L Karst. Plant Physiol., 1992, 139, 742-748.

[41] Jabs, T.; Dietrich, R.A.; Dangl, J.L. Initiation of runaway cell death in an Arabidopsis mutant by extracellular superoxide. Science, 1996, 273, 1853-1856.

[42] Guzzo, S.D.; Harakava, R., Kida, K.; Martins, E.; Roveratti, D. Proteção de cafeeiros contra Hemileia vastatrix por cloreto de benzalcônico composto de amônio quaternário. Summa Phytopatol, 1999, 25, 339-3345.

[43] McCready, R.M.J.; Guggolz, V.; Silveira Owens, H.S. Determination of starch and amylose in vegetables. Anal. Chem., 1950, 22, 1156-1158.

[44] Cipollini, D.F. The induction of soluble peroxidase activity in bean leaves by wind-induced mechanical perturbation. Am. J. Bot, 1998, 85, 1586-1591.

[45] Lagrimini, M.L.; Rothstein, S. Tissue specificity of tobacco peroxidase isozymes and their induction by wounding and tobacco mosaic virus infection. Plant Physiol., 1987, 84, 438-442.

[46] Szabó, C.; Ischiropoulos, H.; Radi. R. Peroxynitrite: biochemistry pathophysiology and development of therapeutics. Natl. Rev. Drug Discov., 2007, 6, 662-680.

[47] Beligni, M.V.; Lamattina, L. Nitric oxide protects against cellular damage produced by methylviologen herbicides in potato plants. Nitric Oxide, 1999, 3, 199-208.

[48] Moy, P.; Qutob, D.; Chapman, B.P.; Atkinson, I.; Gijzen, M. Patterns of gene expression upon infection of soybean plants by Phytophthora sojae. Mol. Plant Microbe Interact., 2004, 17, 1051-1062.

[49] Fridovich, I. Superoxide dismutases: An adaptation to a paramagnetics gas. J. Biol. Chem., 1989, 264, 7761-7764.

[50] Song, X.S.; Wang, Y.J.; Mao, W.H. Shi, K.; Zhou, Y.H.; Nogués, S.; $\mathrm{Yu}$, J.Q. Effects of cucumber mosaic virus infection on electron transport and antioxidant system in chloroplasts and mitochondria of cucumber and tomato leaves. Physiol Plant, 2009, 135, 246-257.

[51] Larson, R.L.; Wintermantel, W.M.; Hill, A.; Fortis, L.; Nunez, A. Proteome changes in sugar beet in response to Beet necrotic yellow vein virus. Physiol Mol Plant Pathol., 2008, 72, 62-72.

[52] Karlsson, M.; Melzer, M.; Prokhorenko, I.; Johansson, T.; Wingsle, G. (2005). Hydrogen peroxide and expression of hipl-superoxide dismutase are associated with the development of secondary cell walls in Zinnia elegans. J. Exp. Bot., 2005, 56, 2085-2093.

[53] Corral-Aguayo, R.D.; Yahia, E.M.; Carrillo-Lopez, A.; GonzálezAguilar, G. Correlation between some nutritional components and the total antioxidant capacity measured with six different assays in eight horticultural crops. J. Agric. Food Chem., 2008, 56, 10498-10504.

[54] Kofalvi, S.A.; Nassuth, A. Influence of wheat streak mosaic virus infection on phenylpropanoid metabolism and the accumulation of phenolics and lignin in wheat. Physiol Mol Plant Pathol., 1995, 47, 365-377.

[55] Anwar, M.N.; Majumder, S.K.; Shetty, H.S. Changes in phenolic acids in sorghum and maize leaves infected with Peronoclespora sorghi. Indian Phytopathol., 1995, 48, 21-26.

[56] Cos, P.; Maes, L.; Vlietinck, A.; Pieters, L. Plant-derived leading compounds for chemotherapy of human immunodeficiency virus HIV infection - an update 1998 - 2007. Planta Med., 2008, 11, 1323-1337.

[57] Abdel-Hameed, E.S. Total phenolic contents and free radical scavenging activity of certain Egyptian Ficus species leaf samples. Food Chem., 2009, 114, 1271-1277.

[58] De Ascensao, A.R.; Dubery, I.A. Panama Disease: Cell Wall Reinforcement in Banana Roots in Response to Elicitors from Fusarium oxysporum $f$ sp cubense Race Four. Phytopathology, 2000, 90, 1173-1180.

[59] Huckelhoven, R. Cell wall-associated mechanisms of disease resistance and susceptibility. Annu. Rev. Phytopathol., 2007, 45, 101-127.

[60] Zeyen, R.J.; Carver, T.L.W.; Lyngkjaer, M.F. Epidermal cell papillae In: The powdery mildew: a comprehensive treatise. Ed.;Belanger, R.R.; Bushnell, W.R. APS Press, 2002, pp. 107-125.

[61] Ming, R.; Hou, S.; Feng, Y.; Yu, Q.; Dionne-Laporte, A.; Saw, J.H.; Senin, P.; Wang, W.; Ly, B.V.; Lewis, K.L. The draft genome of the transgenic tropical fruit tree papaya Carica papaya Linnaeus. Nature, 2008, 452, 991-996.

[62] Passardi, F.; Cosio, C.; Penel, C.; Dunand, C. Peroxidases have more functions than a Swiss army knife. Plant Cell Rep., 2005, 24, 255-265.

[63] Ryals, J.A.; Neuenschwander, U.H.; Willits, M.G.; Molina, A.; Steiner, H.Y.; Hunt,M.D. Systemic acquired resistance. Plant Cell, 1996, 8, 1809-1819.

[64] Ross, A.F. Systemic acquired resistance induced by localized virus infection in plants. Virology, 1961, 14, 340-358.

[65] Uknes, S.; Winter, A.M.; Delaney, T.; Vernooij, B.; Morse, A.; Friedrich, L.; Nye, G.; Potter, S.; Ward, E.; Ryals, J. Biological induction of systemic acquired resistance in Arabidopsis. Mol. Plant Microbe Interact., 1993, 6, 692-698.

[66] Tavares, G.M.; Laranjeira, D.; Luz, E.D.; Silva, T.R.S.; Pirovani, C.P.; de Resende, M.L.V. Ribeiro, P.M. Indução de resistência do mamoeiro à podridão radicular por indutores bióticos e abióticos. Pesquisa Agropecuária Brasileiro, Brasília, 2009, 44, 1416-1423.

[67] Pasquer, F.; Isidore, E.; Zarn, J.; Keller, B. Specific patterns of changes in wheat gene expression after treatment with three antifungal compounds. Plant Mol Biol., 2005, 57, 693-707.

[68] Walters, D.W. Are plants in the field already induced? Implications for practical disease control. Crop Prot., 2009, 28, 459-465.

[69] Herman, M.A.B.; Restrepo, S.; Smart, C.D. Defense gene expression patterns of three SAR-induced tomato cultivars in the field. Physiol Mol Plant Pathol., 2007, 71, 192-200.

[70] Song, F.; Goodman, R.M. Activity of nitric oxide is dependent on but is partially required for function of salicylic acid in the signalling pathway in tobacco systemic acquired resistance. Mol. Plant Microbe Interact., 2001, 14, 1458-1462. 